\title{
Sphaerisporangium flaviroseum sp. nov. and Sphaerisporangium album sp. nov., isolated from forest soil in China
}

Correspondence
Cheng-Lin Jiang
lihxu@ynu.edu.cn
Yan-Ru Cao, ${ }^{1}$ Yi Jiang, ${ }^{1,2}$ Li-Hua $\mathrm{Xu}^{1}$ and Cheng-Lin Jiang ${ }^{1}$

${ }^{1}$ Yunnan Institute of Microbiology, The National Engineering Center for Research of Microbial Pharmaceuticals, Yunnan University, Kunming, Yunnan 650091, PR China

${ }^{2}$ Leibniz-Institut für Meereswissenschaften, IFM-GEOMAR, Düsternbrooker Weg 20, D-24105 Kiel, Germany

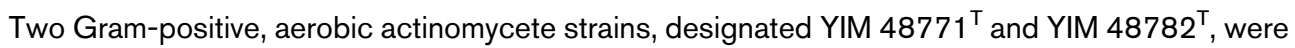
isolated from virgin forest soil samples collected in Hunan Province, China. 16S rRNA gene sequence similarities of the two novel isolates ranged from 96.3 to $97.6 \%$ with species of the genus Sphaerisporangium with validly published names but, in the tree based on 16S rRNA gene sequences, the isolates formed distinct phyletic lines. The level of 16S rRNA gene sequence similarity between the two novel isolates was 97.1\%. DNA-DNA hybridization of strains YIM $48771^{\top}$ and YIM $48782^{\top}$ with recognized species of the genus Sphaerisporangium revealed that the level of DNA-DNA relatedness was below $70 \%$. The DNA G+C contents of strains YIM

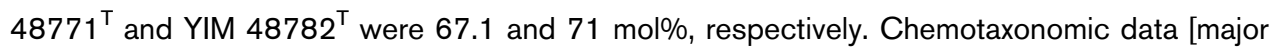
menaquinone, MK-9( $\left.\mathrm{H}_{4}\right)$; major polar lipids, diphosphatidylglycerol, phosphatidylinositol mannoside, phosphatidylethanolamine and phosphoglycolipids; major fatty acids, iso- $\mathrm{C}_{16: 0}$ and 10-methyl $\mathrm{C}_{17: 0}$ ] supported the affiliation of the two isolates with the genus Sphaerisporangium. The results of DNA-DNA hybridization and physiological and biochemical tests allowed genotypic and phenotypic differentiation of the two isolates from recognized Sphaerisporangium species.

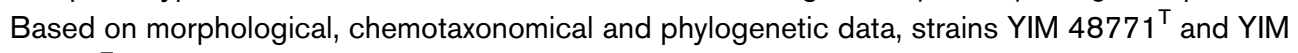
$48782^{\top}$ are considered to represent two novel species of the genus Sphaerisporangium, for which the names Sphaerisporangium flaviroseum sp. nov. (type strain, YIM $48771^{\top}=\mathrm{DSM}$ $45170^{\top}=$ KCTC $19393^{\top}$ ) and Sphaerisporangium album sp. nov. (type strain, YIM $48782^{\top}=$ DSM $45172^{\top}=$ CCTCC AA $208026^{\top}$ ) are proposed.
The genus Sphaerisporangium was described by Ara \& Kudo (2007) and was affiliated with the family Streptosporangiaceae (Goodfellow et al., 1990). Currently, the genus comprises four species, Sphaerisporangium melleum, Sphaerisporangium rubeum, Sphaerisporangium cinnabarinum and Sphaerisporangium viridialbum (Ara \& Kudo, 2007). In the course of an investigation of the actinomycete diversity of Wuling Mountain, China, we isolated two novel strains. Based on the results of the polyphasic taxonomic study, strains YIM $48771^{\mathrm{T}}$ and YIM

Abbreviations: ML, maximum-likelihood; MP, maximum-parsimony; $\mathrm{NJ}$, neighbour-joining.

The GenBank/EMBL/DDBJ accession numbers for the $16 \mathrm{~S}$ rRNA gene

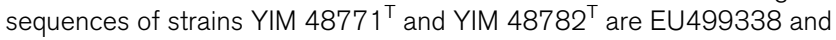
EU499344, respectively.

An extended phylogenetic tree based on 16S rRNA gene sequences, constructed using NJ and ML, showing the relationships of strains YIM $48771^{\top}$ and YIM $48782^{\top}$ and representative species of genera of the family Streptosporangiaceae is available as supplementary material with the online version of this paper.
$48782^{\mathrm{T}}$ should be classified as representing two novel species of the genus Sphaerisporangium.

Strains YIM $48771^{\mathrm{T}}$ and YIM $48782^{\mathrm{T}}$ were isolated, respectively, from soil samples collected from virgin forest at Jinbian Rivulet and Tianzi Mountain, Hunan Province, by using the improved glycerol-asparagine agar [per litre: glycerol, $10 \mathrm{~g}$; asparagine, $1 \mathrm{~g} ; \mathrm{K}_{2} \mathrm{HPO}_{4} \cdot \mathrm{H}_{2} \mathrm{O}, 1 \mathrm{~g}$; $\mathrm{MgSO}_{4} .7 \mathrm{H}_{2} \mathrm{O}, 0.5 \mathrm{~g} ; \mathrm{CaCO}_{3}, 0.3 \mathrm{~g}$; vitamin mixture powder, $3.7 \mathrm{mg}$ (Hayakawa \& Nonomura, 1987); potassium dichromate, $50 \mathrm{mg}$; agar, $20 \mathrm{~g}$; $\mathrm{pH}$ 7.2]. The morphology of spore vesicles grown for 21 days at $28{ }^{\circ} \mathrm{C}$ on ISP 2 medium was observed using light microscopy (BH-2; Olympus) and scanning electron microscopy (Philips XL30; ESEM-TMP). The cultural characteristics of the two strains were determined using ISP 2, ISP 3, ISP 4 and ISP 5 media (Shirling \& Gottlieb, 1966) and Czapek's agar (Pridham \& Lyons, 1980) at $28{ }^{\circ} \mathrm{C}$. The colony colour was determined by means of the ISCC-NBS colour charts (Kelly, 1964). The physiological and biochemical characteristics were determined after incubation at $28{ }^{\circ} \mathrm{C}$ for 
15 days according to Smibert \& Krieg (1994). Carbon and nitrogen source utilization was assessed by using the media and methods of Gordon et al. (1974). Growth at various $\mathrm{pH}$ values was carried out according to Xu et al. (2005) and $\mathrm{NaCl}$ tolerance was examined after incubation at $28{ }^{\circ} \mathrm{C}$ for $7-$ 15 days on ISP 2 medium. Enzyme activities were determined by using API ZYM test kits (bioMérieux). Catalase activity was detected based on bubble formation in $3 \%(\mathrm{v} / \mathrm{v})$ $\mathrm{H}_{2} \mathrm{O}_{2}$ solution. Oxidase activity was determined from the oxidation of $1 \% p$-aminodimethylaniline oxalate.

Cells of strains YIM $48771^{\mathrm{T}}$ and YIM $48782^{\mathrm{T}}$ for chemotaxonomic analysis were grown in ISP 2 medium, with shaking, at $28{ }^{\circ} \mathrm{C}$ and harvested. Analysis of the cellwall amino acids and sugars of whole-cell hydrolysates was carried out as described by Staneck \& Roberts (1974). Polar lipids were extracted, examined by using two-dimensional TLC and identified using published procedures (Minnikin et al., 1979; Collins \& Jones, 1980). Menaquinones were determined using the method of Collins et al. (1977) and analysed by HPLC as described by Tamaoka et al. (1983). Fatty acid analysis was performed using the standard protocol of the MIDI/Hewlett Packard Microbial Identification system (Sasser, 1990; Kämpfer \& Kroppenstedt, 1996) after growth on TSB agar plates [trypticase soy broth (BBL), $3 \%(\mathrm{w} / \mathrm{v})$; Bacto agar (Difco), $1.5 \%(\mathrm{w} / \mathrm{v})]$ for 7 days at $28{ }^{\circ} \mathrm{C}$. The DNA G $+\mathrm{C}$ contents were determined by using HPLC (Mesbah et al., 1989).

The 16S rRNA gene sequences were analysed as described by Li et al. (2007). Phylogenetic analysis was performed using the software package MEGA (Molecular Evolutionary Genetics Analysis) version 3.1 (Kumar et al., 2004) after multiple alignment of data using CLUSTAL_X (Thompson et al., 1997). Distances (using distance options according to the Kimura two-parameter model; Kimura, 1980, 1983) were calculated. The phylogenetic tree was constructed using the neighbour-joining (NJ) (Saitou \& Nei, 1987), maximum-parsimony (MP) (Fitch, 1971) and maximumlikelihood (ML) methods by using PHYLIP v3.6 (Felsenstein,
1993). The stability of relationships was assessed by performing bootstrap analyses based on 1000 resamplings (Felsenstein, 1985).

The results of the cultural characterization of strains YIM $48771^{\mathrm{T}}$ and YIM $48782^{\mathrm{T}}$ are shown in Table 1. Morphological, physiological and biochemical characterization, utilization of carbon and nitrogen sources, amino acids of the cell wall, sugars of whole-cell hydrolysates, polar lipids, fatty acids, menaquinones and DNA G $+\mathrm{C}$ contents are given in Table 2 and the species descriptions.

The phylogenetic tree (Fig. 1) constructed using the three methods (NJ, MP and ML) showed that strains YIM $48771^{\mathrm{T}}$ and YIM $48782^{\mathrm{T}}$ belonged to the genus Sphaerisporangium. 16S rRNA gene sequence similarity matrix analyses showed that the sequence similarities of strain YIM $48771^{\mathrm{T}}$ with S. viridialbum, S. cinnabarinum, S. melleum, S. rubeum and YIM $48782^{\mathrm{T}}$ were, respectively, 97.3, 97.4, 97.2, 96.3 and $97.1 \%$, and those of strain YIM $48782^{\mathrm{T}}$ with the type strains of the four recognized species were $96.9,97.6,96.9$ and $97.1 \%$, respectively.

DNA-DNA hybridization was carried out to determine whether the two strains represent novel species by using the microwell method (Ezaki et al., 1989; He et al., 2005), with the type strains of S. melleum (JCM 13064 ${ }^{\mathrm{T}}$ ), S. rubeum (JCM $\left.13067^{\mathrm{T}}\right)$, S. cinnabarinum (JCM 3291 ${ }^{\mathrm{T}}$ ) and S. viridialbum (JCM $3027^{\mathrm{T}}$ ), which were kindly provided by the Japan Collection of Micro-organisms (JCM; Hirosawa, Japan). DNA-DNA reassociation values between strain YIM $48771^{\mathrm{T}}$ and S. viridialbum, S. cinnabarinum, S. melleum, S. rubeum were $50,41,52$ and $44 \%$, respectively, whereas the values for strain YIM $48782^{\mathrm{T}}$ were $51,46,48$ and $48 \%$, respectively. The DNA-DNA relatedness between strains YIM $48771^{\mathrm{T}}$ and YIM $48782^{\mathrm{T}}$ was $64 \%$. These values were lower than the cutoff point recommended for the circumscription of bacterial genomic species (Wayne et al., 1987).

Comparison of strains YIM $48771^{\mathrm{T}}$ and YIM $48782^{\mathrm{T}}$ with recognized species of the genus Sphaerisporangium (Table 2)

Table 1. Cultural characteristics of strains $\mathrm{YIM} 48771^{\top}$ and $\mathrm{YIM} 48782^{\top}$

Diffusible pigments were not produced on any of the media listed. ISP, International Streptomyces project. - , No growth; + , growth; ++ , good growth.

\begin{tabular}{|c|c|c|c|c|c|c|c|c|}
\hline \multirow[t]{3}{*}{ Medium } & \multicolumn{4}{|c|}{ YIM $48771^{T}$} & \multicolumn{4}{|c|}{ YIM $48782^{T}$} \\
\hline & \multicolumn{2}{|c|}{ Aerial mycelium } & \multicolumn{2}{|c|}{ Substrate mycelium } & \multicolumn{2}{|c|}{ Aerial mycelium } & \multicolumn{2}{|c|}{ Substrate mycelium } \\
\hline & Formation & Colour & Growth & Colour & Formation & Colour & Growth & Colour \\
\hline Czapek's agar & - & - & + & White & + & White & + & White \\
\hline $\begin{array}{l}\text { Yeast extract-malt extract } \\
\text { (ISP 2) }\end{array}$ & + & White & ++ & Deep yellow pink & ++ & White & ++ & Pale grey \\
\hline Oatmeal agar (ISP 3) & + & White & ++ & Soft yellow pink & ++ & White & ++ & Yellow white \\
\hline $\begin{array}{l}\text { Inorganic salt-starch agar } \\
\text { (ISP 4) }\end{array}$ & - & - & + & White & + & White & + & White \\
\hline Glycerol-asparagine (ISP 5) & - & - & + & White & + & White & + & White \\
\hline
\end{tabular}




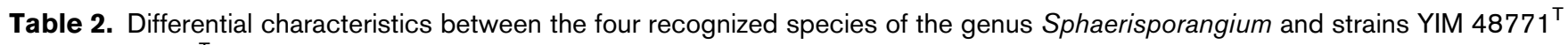
and YIM $48782^{\top}$

Strains: 1, S. flaviroseum sp. nov. YIM $48771^{\mathrm{T}}$; 2, S. album sp. nov. YIM $48782^{\mathrm{T}}$; 3, S. viridialbum JCM 3027 $;$ 4, S. cinnabarinum JCM $3291^{\mathrm{T}}$; 5, S. melleum JCM $13064^{\mathrm{T}}$; 6, S. rubeum JCM $13067^{\mathrm{T}}$. ND, Not determined; +, positive; -, negative; (+), weak growth.

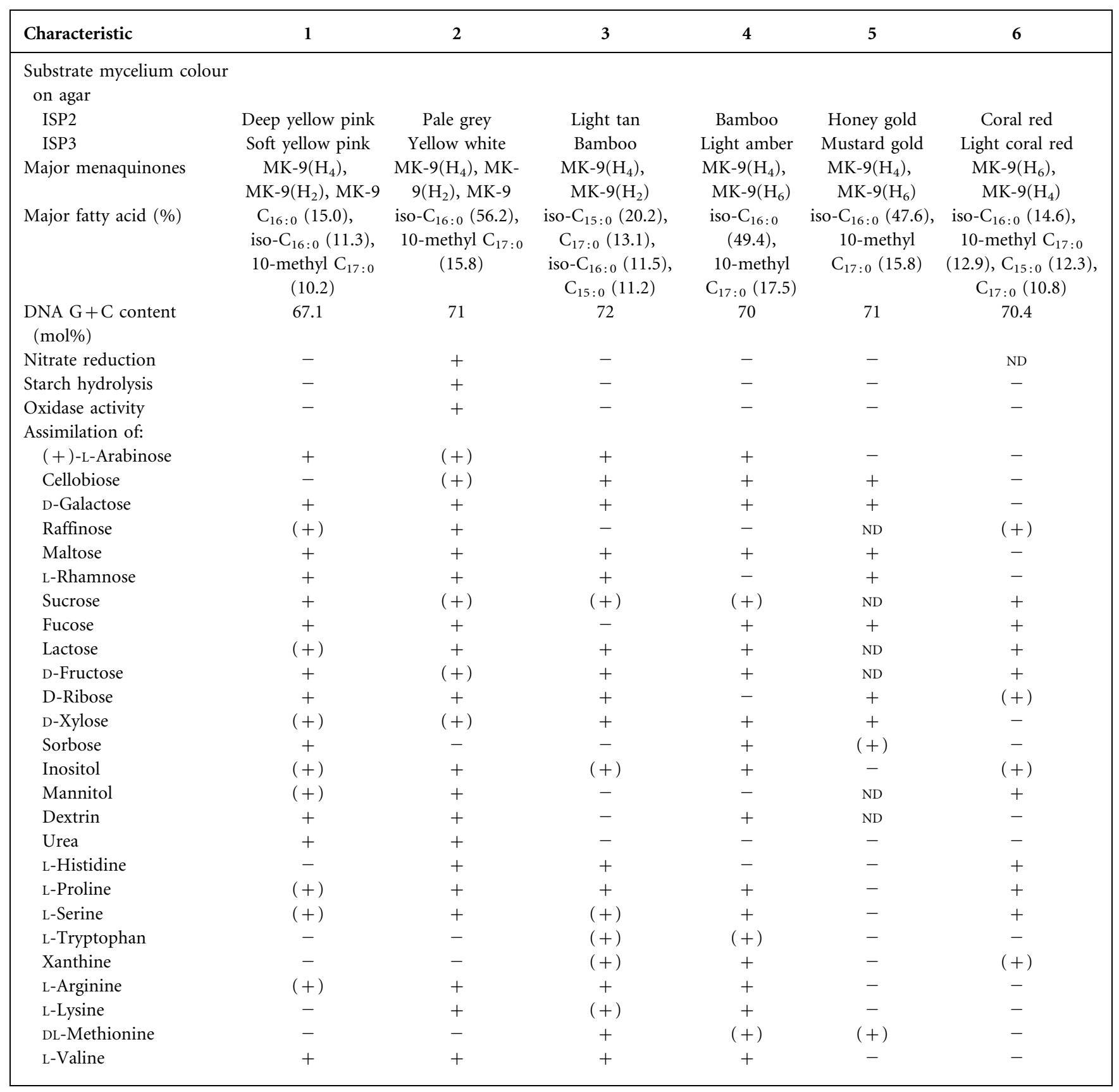

showed that the amounts of MK-9 for the two strains were, respectively, 28.1 and $29.0 \%$, but were present in smaller amounts $(<10 \%)$ in the recognized species. The amounts of the fatty acids $\mathrm{C}_{15: 0}$, iso- $\mathrm{C}_{15: 0}$ and $\mathrm{C}_{17: 0}$ of the two strains were less than $10 \%$, and the fatty acid $\mathrm{C}_{17: 1} \omega 8 \mathrm{c}$ was not present, whereas the amounts of these fatty acids for $S$. viridialbum and S. rubeum were greater than $10 \%$. The amount of $\mathrm{C}_{16: 0}$ for YIM $48771^{\mathrm{T}}$ was $15.02 \%$, but those for recognized species of Sphaerisporangium and YIM $48782^{\mathrm{T}}$ were less than $10.3 \%$. Strains YIM $48771^{\mathrm{T}}$ and YIM $48782^{\mathrm{T}}$ contained diphosphatidylglycerol, phosphatidylinositol mannoside, phosphatidylethanolamine and phosphoglycolipids, similar to recognized species of the genus Sphaerisporangium. In addition, strain YIM $48771^{\mathrm{T}}$ contained phosphatidylmethylethanolamine and phosphatidylinositol, and strain YIM $48782^{\mathrm{T}}$ phosphatidylinositol. The DNA G $+C$ content of YIM $48771^{\mathrm{T}}$ was $67.1 \%$, which was less than those of recognized species of Sphaerisporangium 


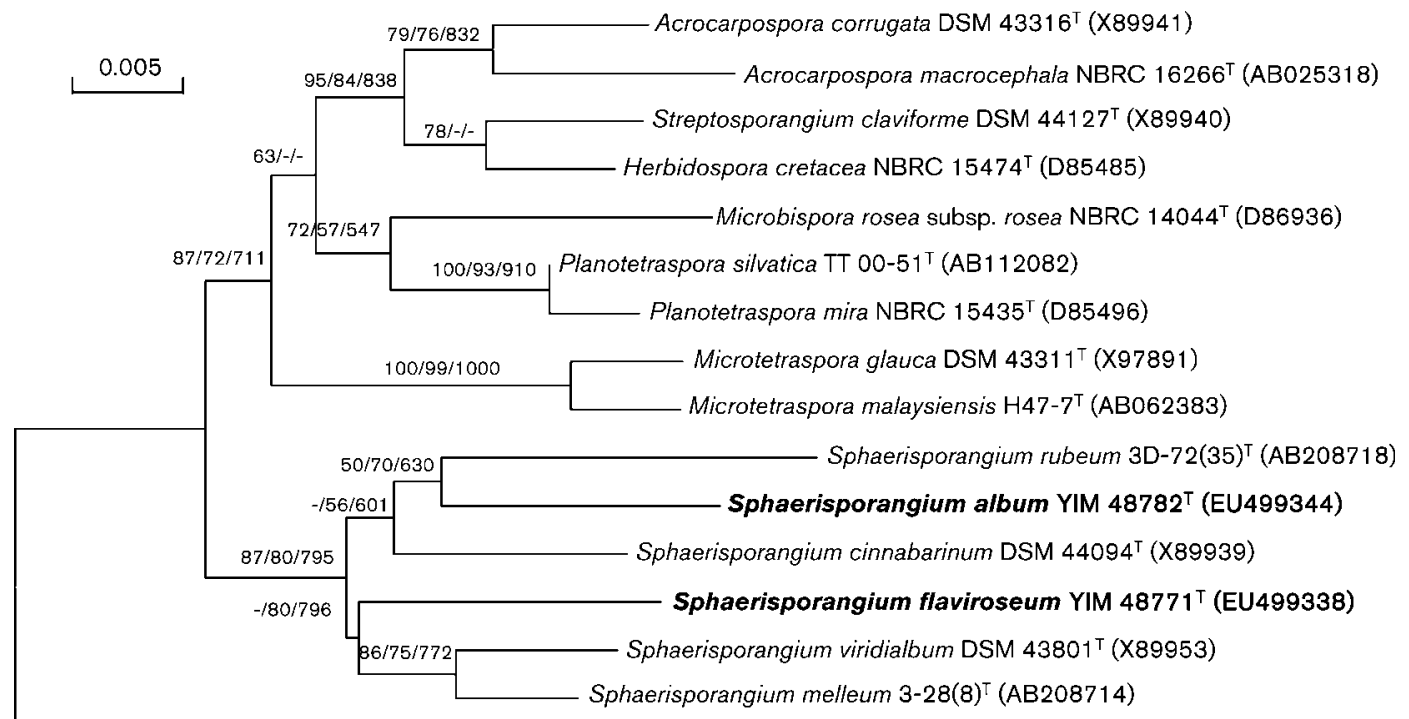

Actinomadura madura JCM $7436^{\mathrm{T}}$ (U58527)

Fig. 1. Phylogenetic dendrogram derived from 16S rRNA gene sequences showing the relationships between strains YIM $48771^{\top}$ and YIM $48782^{\top}$ and representative species of genera of the family Streptosporangiaceae. The dendrogram was constructed by using the NJ, MP and ML methods. Numbers (NJ/MP/ML) on branch nodes are bootstrap values (based on 1000 resamplings; only values greater than $50 \% / 500$ are given). Bar, $0.5 \%$ sequence divergence. An extended version of this tree is available as Supplementary Fig. S1 (in IJSEM Online).

and strain YIM $48782^{\mathrm{T}}(71 \%)$. Therefore, strains YIM $48771^{\mathrm{T}}$ and YIM $48782^{\mathrm{T}}$ should be considered as representing two novel species of the genus Sphaerisporangium, for which the names Sphaerisporangium flaviroseum sp. nov. and Sphaerisporangium album sp. nov. are proposed.

\section{Emended description of the genus Sphaerisporangium Ara and Kudo 2007}

In addition to the description given by Ara \& Kudo (2007), major menaquinones are MK- $9\left(\mathrm{H}_{4}\right), \mathrm{MK}-9\left(\mathrm{H}_{6}\right), \mathrm{MK}-9\left(\mathrm{H}_{2}\right)$ and MK-9. The DNA G $+\mathrm{C}$ contents are $67-72 \mathrm{~mol} \%$.

\section{Description of Sphaerisporangium flaviroseum sp. nov.}

Sphaerisporangium flaviroseum (fla.vi.ro'se.um. L. adj. flavus yellow; L. adj. roseus rose; N.L. neut. adj. flaviroseum yellowish-rose coloured).

Gram-positive. Forms yellow-pink substrate mycelia and white aerial mycelia. No diffusible pigment is produced on any of the media tested. Spherical and pyriform spore vesicles are borne on aerial mycelia. Grows at $\mathrm{pH} 6-8$ and in $1 \% \mathrm{NaCl}$. Catalase- and oxidase-negative. Activities of alkaline phosphatase, esterase (C4), esterase lipase (C8), leucine arylamidase, valine arylamidase, trypsin, $\alpha$-chymotrypsin, acid phosphatase, naphthol-AS-BI-phosphohydrolase, $\beta$-galactosidase, $\alpha$-glucosidase, $\beta$-glucosidase, $N$-acetyl$\beta$-glucosaminidase, $\alpha$-mannosidase and $\alpha$-fucosidase are positive. Activities of $\beta$-glucuronidase, cystine arylamidase, $\alpha$-galactosidase and lipase (C14) are negative. Gelatin liquification, milk coagulation and peptonization, hydrolysis of starch, nitrate reduction, $\mathrm{H}_{2} \mathrm{~S}$ production and hydrolysis of cellulose are negative. Glucose, fructose, galactose, mannose, arabinose, xylose, ribose, rhamnose, sucrose, lactose, maltose, melibiose, raffinose, starch, sorbose, dextrin, fucose, inositol, mannitol, aesculin, galactose are utilized as sole carbon sources, but cellobiose, xylitol, erythritol and amygdalin are not. Hydrolyses urea, proline, L-phenylalanine, L-arginine, L-valine, serine and ornithine, but not glycine, L-tryptophan, histidine, methionine, lysine or xanthine. Major menaquinones are MK- $9\left(\mathrm{H}_{4}\right)(31.9 \%)$, MK-9 $\left(\mathrm{H}_{2}\right)(29.8 \%)$ and MK-9 $(28.1 \%)$. Cellular fatty acids are iso- $\mathrm{C}_{15: 0}(6.8 \%), \mathrm{C}_{15: 0}(5.0 \%)$, iso- $\mathrm{C}_{16: 0}(11.3 \%)$, $\mathrm{C}_{16: 1}(5.0 \%), \mathrm{C}_{16: 0}(15.0 \%), \mathrm{C}_{17: 1}(7.6 \%), \mathrm{C}_{17: 0}(9.0 \%)$, 10-methyl $\mathrm{C}_{17: 0}(10.2 \%)$, anteiso- $\mathrm{C}_{18: 0}(5.0 \%)$ and $\mathrm{C}_{18: 1}$ $(6.3 \%)$. The diagnostic amino acid of the peptidoglycan is meso-DAP. Whole-cell hydrolysates contain ribose, madurose, galactose, glucose and mannose. Phospholipids consist of diphosphatidylglycerol, phosphatidylinositol, phosphatidylinositol mannoside, phosphatidylethanolamine, phosphatidylmethylethanolamine and phosphoglycolipids. The $\mathrm{G}+\mathrm{C}$ content of the DNA of the type strain is $67.1 \mathrm{~mol} \%$.

The type strain, YIM $48771^{\mathrm{T}}\left(=\mathrm{DSM} 45170^{\mathrm{T}}=\mathrm{KCTC}\right.$ $\left.19393^{\mathrm{T}}\right)$, was isolated from soil of Hunan, China.

\section{Description of Sphaerisporangium album sp. nov.}

Sphaerisporangium album (al'bum. L. neut. adj. album white). 
Gram-positive. Forms pale-grey substrate mycelia and white aerial mycelia. No diffusible pigment is produced on any of the media tested. Spherical and pyriform spore vesicles are borne on aerial mycelia. Grows in $2 \% \mathrm{NaCl}$. Catalase- and oxidase-positive. Activities of alkaline phosphatase, esterase (C4), esterase lipase (C8), lipase (C14), leucine arylamidase, valine arylamidase, trypsin, $\alpha$ chymotrypsin, acid phosphatase, naphthol-AS-BI-phosphohydrolase, $\beta$-galactosidase, $\alpha$-glucosidase, $\beta$-glucosidase, $N$-acetyl- $\beta$-glucosaminidase and $\alpha$-mannosidase are positive. Cystine arylamidase, $\alpha$-galactosidase, $\beta$-glucuronidase and $\alpha$-fucosidase are negative. Hydrolysis of starch and nitrate reduction are positive, but gelatin liquification, milk coagulation and peptonization, $\mathrm{H}_{2} \mathrm{~S}$ production and hydrolysis of cellulose are negative. Glucose, fructose, galactose, mannose, arabinose, xylose, ribose, rhamnose, sucrose, lactose, maltose, melibiose, raffinose, cellobiose, starch, dextrin, fucose, inositol, mannitol, aesculin, galactose are utilized, but sorbin, xylitol, erythritol or amygdalin are not. Hydrolyses urea, proline, serine, ornithine, Lphenylalanine, L-arginine, L-valine, histidine and lysine, but not glycine, L-tryptophan, methionine or xanthine. Major menaquinones are MK-9 $\left(\mathrm{H}_{4}\right)(32.5 \%)$, MK-9 $\left(\mathrm{H}_{2}\right)$ $(31.3 \%)$ and MK-9 $(29.0 \%)$. Cellular fatty acids are iso$\mathrm{C}_{15: 0}(4.8 \%)$, iso- $\mathrm{C}_{16: 0}(56.2 \%)$, and 10 -methyl $\mathrm{C}_{17: 0}$ $(15.8 \%)$. Diagnostic amino acid of peptidoglycan is mesoDAP. Whole-cell hydrolysates contain ribose, madurose, galactose, glucose and mannose. Phospholipids consist of diphosphatidylglycerol, phosphatidylinositol, phosphatidylinositol mannoside, phosphatidylethanolamine and phosphoglycolipids. The $\mathrm{G}+\mathrm{C}$ content of the DNA of the type strain is $71 \mathrm{~mol} \%$.

The type strain, YIM $48782^{\mathrm{T}}\left(=\mathrm{DSM} 45172^{\mathrm{T}}=\right.$ CCTCC AA $208026^{\mathrm{T}}$ ), was isolated from soil of Hunan, China.

\section{Acknowledgements}

This research was supported by the National Basic Research Program of China (No. 2004CB719601), the National Natural Science Foundation of China (No. 30560001, 30600001), the International Cooperative Program of the Ministry of Science of Technology, P. R. China (2006DFA33550) and the Yunnan Provincial International cooperative Program (No. 2005GH21).

\section{References}

Ara, I. \& Kudo, T. (2007). Sphaerosporangium gen. nov., a new member of the family Streptosporangiaceae, with descriptions of three new species as Sphaerosporangium melleum sp. nov., Sphaerosporangium rubeum sp. nov. and Sphaerosporangium cinnabarinum sp. nov., and transfer of Streptosporangium viridialbum Nonomura and Ohara 1960 to Sphaerosporangium viridialbum comb. nov. Actinomycetologica 21, $11-21$.

Collins, M. D. \& Jones, D. (1980). Lipids in the classification and identification of coryneform bacteria containing peptidoglycans based on 2, 4-diaminobutyric acid. J Appl Bacteriol 48, 459-470.

Collins, M. D., Pirouz, T., Goodfellow, M. \& Minnikin, D. E. (1977). Distribution of menaquinones in actinomycetes and corynebacteria. J Gen Microbiol 100, 221-230.
Ezaki, T., Hashimoto, Y. \& Yabuuchi, E. (1989). Fluorometric deoxyribonucleic acid-deoxyribonucleic acid hybridization in microdilution wells as an alternative to membrane filter hybridization in which radioisotopes are used to determine genetic relatedness among bacterial strains. Int J Syst Bacteriol 39, 224-229.

Felsenstein, J. (1985). Confidence limits on phylogenies: an approach using the bootstrap. Evolution 39, 783-791.

Felsenstein, J. (1993). PHYLIP (phylogeny inference package), version 3.6c. Distributed by the author. Department of Genome Sciences, University of Washington, Seattle, USA.

Fitch, W. M. (1971). Toward defining the course of evolution: minimum change for a specific tree topology. Syst Zool 20, 406-416.

Goodfellow, M., Stanton, L. J., Simpson, K. E. \& Minnikin, D. E. (1990). Numerical and chemical classification of Actinoplanes and some related actinomycetes. J Gen Microbiol 136, 19-36.

Gordon, R. E., Barnett, D. A., Handerhan, J. E. \& Pang, C. H.-N. (1974). Nocardia coeliaca, Nocardia autotrophica, and the nocardin strain. Int J Syst Bacteriol 24, 54-63.

Hayakawa, M. \& Nonomura, H. (1987). Humic acid-vitamin agar, a new medium for selective isolation of soil actinomycetes. J Ferment Technol 65, 501-509.

He, L., Li, W., Huang, Y., Wang, L., Liu, Z., Lanoot, B., Vancanneyt, M. \& Swings, J. (2005). Streptomyces jietaisiensis sp. nov., isolated from soil in northern China. Int J Syst Evol Microbiol 55, 1939-1944.

Kämpfer, P. \& Kroppenstedt, R. M. (1996). Numerical analysis of fatty acid patterns of coryneform bacteria and related taxa. Can J Microbiol 42, 989-1005.

Kelly, K. L. (1964). Inter-Society Color Council - National Bureau of Standards Color Name Charts Illustrated with Centroid Colors. Washington, DC: US Government Printing Office.

Kimura, M. (1980). A simple method for estimating evolutionary rates of base substitutions through comparative studies of nucleotide sequences. J Mol Evol 16, 111-120.

Kimura, M. (1983). The Neutral Theory of Molecular Evolution. Cambridge: Cambridge University Press.

Kumar, S., Tamura, K. \& Nei, M. (2004). MEGA3: Integrated software for Molecular Evolutionary Genetics Analysis and sequence alignment. Brief Bioinform 5, 150-163.

Li, W. J., Xu, P., Schumann, P., Zhang, Y. Q., Pukall, R., Xu, L. H., Stackebrandt, E. \& Jiang, C. L. (2007). Georgenia ruanii sp. nov., a novel actinobacterium isolated from forest soil in Yunnan (China) and emended description of the genus Georgenia. Int J Syst Evol Microbiol 57, 1424-1428.

Mesbah, M., Premachandran, U. \& Whitman, W. B. (1989). Precise measurement of the $\mathrm{G}+\mathrm{C}$ content of deoxyribonucleic acid by highperformance liquid chromatography. Int J Syst Bacteriol 39, 159-167.

Minnikin, D. E., Collins, M. D. \& Goodfellow, M. (1979). Fatty acid and polar lipid composition in the classification of Cellulomonas, Oerskovia and related taxa. J Appl Bacteriol 47, 87-95.

Pridham, T. G. \& Lyons, A. J. (1980). Methodologies for Actinomycetales with special reference to streptomycetes and streptoverticillia. In Actinomycete Taxonomy, pp. 153-224. Edited by A. Dietz \& D. W. Thayer. Special publication no. 6. Arlington, VA: Society for Industrial Microbiology.

Saitou, N. \& Nei, M. (1987). The neighbor-joining method: a new method for reconstructing phylogenetic trees. Mol Biol Evol 4, 406425.

Sasser, M. (1990). Identification of bacteria by gas chromatography of cellular fatty acids, MIDI Technical Note 101. Newark, DE: MIDI Inc.

Shirling, E. B. \& Gottlieb, D. (1966). Methods for characterization of Streptomyces species. Int J Syst Bacteriol 16, 313-340. 
Smibert, R. M. \& Krieg, N. R. (1994). Phenotypic characterization. In Methods for General and Molecular Bacteriology, pp. 607-654. Edited by P. Gerhardt, R. G. E. Murray, W. A. Wood \& N. R. Krieg. Washington, DC: American Society for Microbiology.

Staneck, J. L. \& Roberts, G. D. (1974). Simplified approach to identification of aerobic actinomycetes by thin layer chromatography. Appl Microbiol 28, 226-231.

Tamaoka, J., Katayama-Fujimura, Y. \& Kuraishi, H. (1983). Analysis of bacterial menaquinone mixtures by high performance liquid chromatography. J Appl Bacteriol 54, 31-36.

Thompson, J. D., Gibson, T. J., Plewniak, F., Jeanmougin, F. \& Higgins, D. G. (1997). The CLUSTAL_X windows interface: flexible strategies for multiple sequence alignment aided by quality analysis tools. Nucleic Acids Res 25, 4876-4882.

Wayne, L. G., Brenner, D. J., Colwell, R. R., Grimont, P. A. D., Kandler, O., Krichevsky, M. I., Moore, L. H., Moore, W. E. C., Murray, R. G. E. \& other authors (1987). International Committee on Systematic Bacteriology. Report of the ad hoc committee on reconciliation of approaches to bacterial systematics. Int $J$ Syst Bacteriol 37, 463-464.

Xu, P., Li, W.-J., Tang, S.-K., Zhang, Y.-Q., Chen, G.-Z., Chen, H.-H., Xu, L.-H. \& Jiang, C.-L. (2005). Naxibacter alkalitolerans gen. nov., sp. nov., a novel member of the family Oxalobacteraceae isolated from China. Int J Syst Evol Microbiol 55, 1149-1153. 